\title{
A new record of Podocarpaceae fossil wood from Miocene strata, Northern Taiwan
}

\author{
Yuan-Po $\mathrm{Lo}^{1}$ and Jer-Ming $\mathrm{Hu}^{1,2, *}$ \\ ${ }^{1}$ Institute of Ecology and Evolutionary Biology, National Taiwan University, Taipei City, Taiwan \\ ${ }^{2}$ NTU Herbarium (TAI), National Taiwan University, Taipei City, Taiwan
}

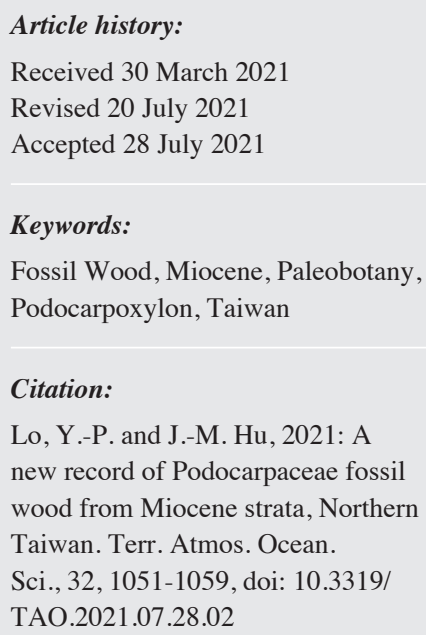

\begin{abstract}
Podocarpaceae is a family distributed in the tropical and subtropical regions. Although there are several extant species in Taiwan, the fossil record of Podocarpaceae is only present in pollen records. Based on thin sections and wood anatomical observations, this article reports the first record of Podocarpaceae macrofossil and a new species in Taiwan, Podocarpoxylon nageioides Y.-P. Lo and J.-M. Hu, sp.nov., from the Miocene strata, Northern Taiwan. The discovery of fossil wood provides a new reference for research in biogeography and fossil plant in Taiwan.
\end{abstract}

\section{INTRODUCTION}

The research reports of plant macrofossils in Taiwan are scarce and most of the records are leaf impressions. Chaney and Chuang (1968) published several species of leaf fossils, while Canright (1972) described the leafy branches and single ovule cone of Metasequoia from Shihti Formation. These two papers were the first reports with a complete information and discussion of plant fossils in Taiwan. Li (2000) introduced the Miocene floras of Taiwan, not only focused on leaf identification but also included seeds and woods (Li et al. 1999, 2003; Li 2000; Uemura and Li 2006). Compared with microfossils such as spores and pollens, the records of fossil woods in Taiwan are sporadic. The fossil wood is a direct evidence to prove the existence of plant species, it provides useful data for reconstructing paleoenvironment and understanding the dominant species in paleoforest.

Despite the diversity and endemism of extant conifer genera in Taiwan is quite high, there are only a few fossil conifer records reported in Taiwan, in particular, there is still no macrofossil evidence of Podocarpaceae known to date. Podocarpaceae is the second-largest conifer family, with 19 genera, widely distributed in the tropical and subtropical regions. Especially in the southern hemisphere such as New Zealand, Tasmania, Nouvelle-Calédonie and Patagonia, there are about 6 - 7 endemic genera (Eckenwalder 2009; Yang et al. 2017). According to the Flora of Taiwan $2^{\text {nd }}$ ed. (Li et al. 1994) and the Red List of Vascular Plants of Taiwan (Editorial Committee of the Red List of Taiwan Plants 2017), there are two extant genera of Podocarpaceae in Taiwan, Nageia and Podocarpus, about 5 - 6 species in total. There are various types of Podocarpaceae fossils found all over the world, and the wood fossil hotspots of Podocarpaceae is also in the tropical region as in the modern genera. Based on a paleobotanical survey in northern Taiwan, we look forward to provide an independent evidence, the discovery of fossil wood of Podocarpaceae, for a new addition to the plant fossil database in Taiwan and for the research in plant distribution or biogeography.

\footnotetext{
* Corresponding author

E-mail:jmhu@ntu.edu.tw
} 


\section{METHODOLOGY}

Location of the samples in this article is in Wanli distinct, Northern Taiwan, with numerous leaf fossils (Fig. 1). According to the environment and buried condition, these plant fossils should be artificially transferred with abandoned rocks from other coal mines while it might cause problems in judging the original stratigraphic time. Plant fossils are usually found with the coal mining, and most of leaf fossil records in Taiwan were found in the Miocene formations which have coal bed. There are three famous Formations with coal beds in Northern Taiwan, Mushan Formation, Shihti Formation and Nanchuang Formation (Chen and $\mathrm{Yu}$ 2016). Ho (1966) described the characteristics of Shihti Formation as having the scarcity of marine organisms, the presence of plant remains, and the occurrence of non- persistent thin coal beds. With paleontological and physical correlation, the property and texture of adjacent rock showed the gray siltstone with the relatively fine grain size and with the remain of plants, similar to the Shihti Formation or the Mushan Formation (Chou 1962; Ho 1966; Yue and Teng 2000).

Identification of the sample was made by sectioning them into thin slides in transverse, radial and tangential sections (specimen number WL001 - WL005), and observed by light and dissecting microscope and microphotographs taken with digital cameras (Canon powershot G9; Nikon D610). The main terminological description of wood ana- tomical structure and characters follows IAWA Committee's (2004) list of microscopic features for softwood identification. There are some features noted in reports which differ from IAWA Committee (2004), but followed the original description and the definition from Philippe and Bamford (2008). The result is compared with the similar modern and fossil wood samples information carefully obtained from several reports and integrated database from websites such as Paleobiology Database (Peters and McClennen 2016) and Inside Wood (Wheeler 2011).

\section{RESULTS}

\section{- Systematics:}

Order: Araucariales Gorozh.

Family: Podocarpaceae Endl.

Genus: Podocarpoxylon Gothan.

Species: Podocarpoxylon nageioides Y.-P. Lo and J.-M. $\mathrm{Hu}$, sp. nov.

- Holotype: WL001.

- Paratypes: WL002, WL003, WL004, WL005.

- Type locality and horizon: Wanli Dist., New Taipei City, Taiwan (R.O.C.). Early Miocene. (The detailed locality note was recorded and conserved with the holotype in $\mathrm{Na}-$ tional Taiwan University Herbarium.)

- Repository: National Taiwan University Herbarium (TAI), Taipei, Taiwan.

- Etymology: The specific name "nageioides" means that
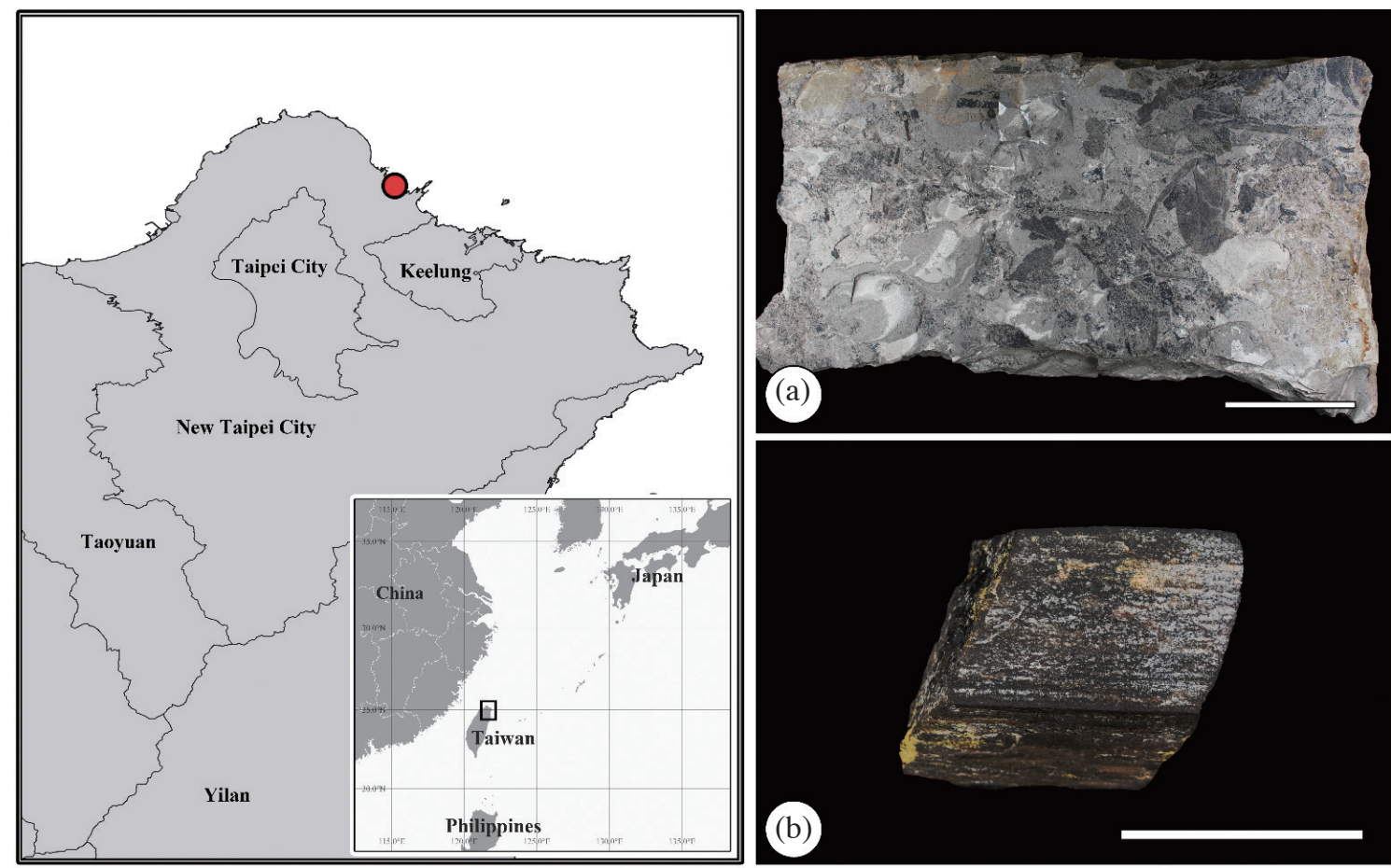

Fig. 1. The sampling locality (red spot) is in Wanli distinct, Northern Taiwan. (a) Leaf fossils from the same locality. Scale bar $=10 \mathrm{~cm}$. (b) The fossil wood sample of this article (WL001). Scale bar $=5 \mathrm{~cm}$. 
the wood structure characteristic is similar to the modern genus Nageia.

- Diagnosis: Growth ring boundaries indistinct. Intertracheary pitting bordered, uniseriate, without helical thickenings. Average longitudinal tracheid length short. Axial parenchyma diffused, transverse end walls smooth. End and horizontal wall of ray parenchyma cells smooth; horizontal wall thin, indentures absent. Ray tracheids absent. Cross-field pits cupressoid, some of taxodioid, 1 - 2 pits per cross-field. Ray height medium, uniseriate. Resin canal absent, crystal absent.

\section{- Description:}

Tracheids: Growth ring boundaries indistinct, latewood indistinct and narrow with 1 - 3 rows of cells (Fig. 2a). Transition from earlywood to latewood gradual. The shape of earlywood tracheids in transverse section square or polygonal (Fig. 2b). Tracheid length range 1345.6 - 5083.3 $\mu \mathrm{m}$, average $2981.3 \pm 1049.9 \mu \mathrm{m}$. Tangential diameter range 22.8 - $46.7 \mu \mathrm{m}$, average $33.7 \pm 6.1 \mu \mathrm{m}$. Intertracheary radial pitting exclusively in one row (uniseriate) (Fig. $2 \mathrm{c}$ ), pits bordered. Torus could not be recognized easily due to preservation (Fig. 2f). Helical thickenings absent; resin canals absent; crystals absent.

Longitudinal parenchyma: Axial parenchyma abundant and diffuse, tangentially zonate not observed (Fig. 2a). End walls of parenchyma cells smooth (Fig. 2e).

Rays: Uniseriate rays, medium, 1 - 23 cells in height, average $6.47 \pm 4.9$ cells (Fig. 2h). Rays per square millimeter in tangential section $25 \pm 2.97 \mathrm{~mm}^{-2}$. Horizontal walls of ray parenchyma thin (Fig. 2g); end and horizontal wall of ray parenchyma cells smooth (Fig. 2g). Indentures absent. Ray tracheids absent. Cross-field pits cupressoid, some taxodioid, aperture vertical to rarely oblique, 1 - 2 pits, mostly 2 in per cross-field, horizontally arranged. Each pit vertical diameter range $6.1-12.5 \mu \mathrm{m}$, average $8.9 \pm 1.6 \mu \mathrm{m}$ (Fig. $2 \mathrm{~d}$ ).

\subsection{Comparison with Modern Species}

Absence of druses (idioblasts), helical thickenings, ray tracheids, and resin ducts, indicate that the sample from Wanli can be excluded from Ginkgoaceae, Taxaceae, and most Pinaceae species (Phillips 1948; IAWA Committee 2004). Intertracheary pitting uniseriate and cross-field pits cupressoid or taxodioid are not the characteristic of Araucariaceae (Greguss 1955; IAWA Committee 2004). Most species of Cupressaceae (including Taxodiaceae) have abundant axial parenchyma with tangentially zonate, and distinct growth rings, the transition from earlywood to latewood abrupt or gradual (Greguss 1955; Jiang et al. 2010). As noted above, the features of the sample from Wanli are consistent with Podocarpaceae.

The genera of Podocarpaceae currently native to Taiwan and nearby area, such as China, include Dacrycarpus, Dacrydium, Nageia, and Podocarpus (Jiang et al. 2010).
Main identified features: growth ring indistinct, abundant of axial parenchyma and the height of rays, also compared with microscopic slides of wood structure and record of modern material, the fossil wood sample from Wanli could be distinguished from species of Dacrycarpus and Dacrydium (Cheng et al. 1992; Heinz 2004; Jiang et al. 2010). The sample most features are similar to Nageia or a few other species of Podocarpus, but there are some differences can be discriminated. Most Podocarpus species with the distinct growth ring and transition from earlywood to latewood gradual, axial parenchyma abundant, diffuse or tangentially zonate. And with the most similar genus to the sample from Wanli, Nageia with the cross-field pits cupressoid, 1 - 4, mostly 1 - 2 in per cross-field (Jiang et al. 2010). However, considering the wood anatomical traits and the geological age, it seems controversial to classify the sample from Wanli as any extant genus of Podocarpaceae.

\subsection{Comparison with Fossil Species}

By comparing to the nearest living relatives, we interpreted that the fossil wood belongs to the genera of Podocarpaceae or closely related family. The result shows that the sample from Wanli is very similar to the fossil genus Podocarpoxylon and can be distinguished from the other fossil genera of Podocarpaceae.

Philippe and Bamford (2008) integrated and translated several original characteristic description and publications of conifer-like woods from Mesozoic, including most genera of the fossil wood of Podocarpaceae. In recent years, there are still new fossil genus of Podocarpaceae been discovered and erected, such as Prumnopityoxylon (Franco and Brea 2015). The major different characteristics of related taxa distinguished from the sample from Wanli, are as follows: Circoporoxylon with small round or at most ovoid oopores in the cross-fields (Philippe and Bamford 2008; Philippe and Wilde 2020); Metapodocarpoxylon with araucarian type of radial pitting (Dupéron-Laudoueneix and Pons 1985); Microcachryxylon with 1 - 2 large, irregularly shaped pits of cross-field (Philippe and Bamford 2008); Phyllocladoxylon with typically large oopores of the cross-fields (Gothan 1905; Philippe and Bamford 2008); Protophyllocladoxylon with araucarioid radial pitting and phyllocladoid pits of cross-field (Kräusel 1939); Protopodocarpoxylon tracheid pits in various transitional arrangement, axial parenchyma rare (Philippe and Bamford 2008); Prumnopityoxylon with absence of axial parenchyma (Franco and Brea 2015). In addition, there are two genera Dacrydioxylon and Mesembrioxylon also belong to Podocarpaceae but they were proved to be illegitimate names (Philippe et al. 1999; Bamford and Philippe 2001).

Gothan (1905) erected two genera of Podocarpaceae, Phyllocladoxylon, and Podocarpoxylon. According to Gothan's original description in German and the translated 

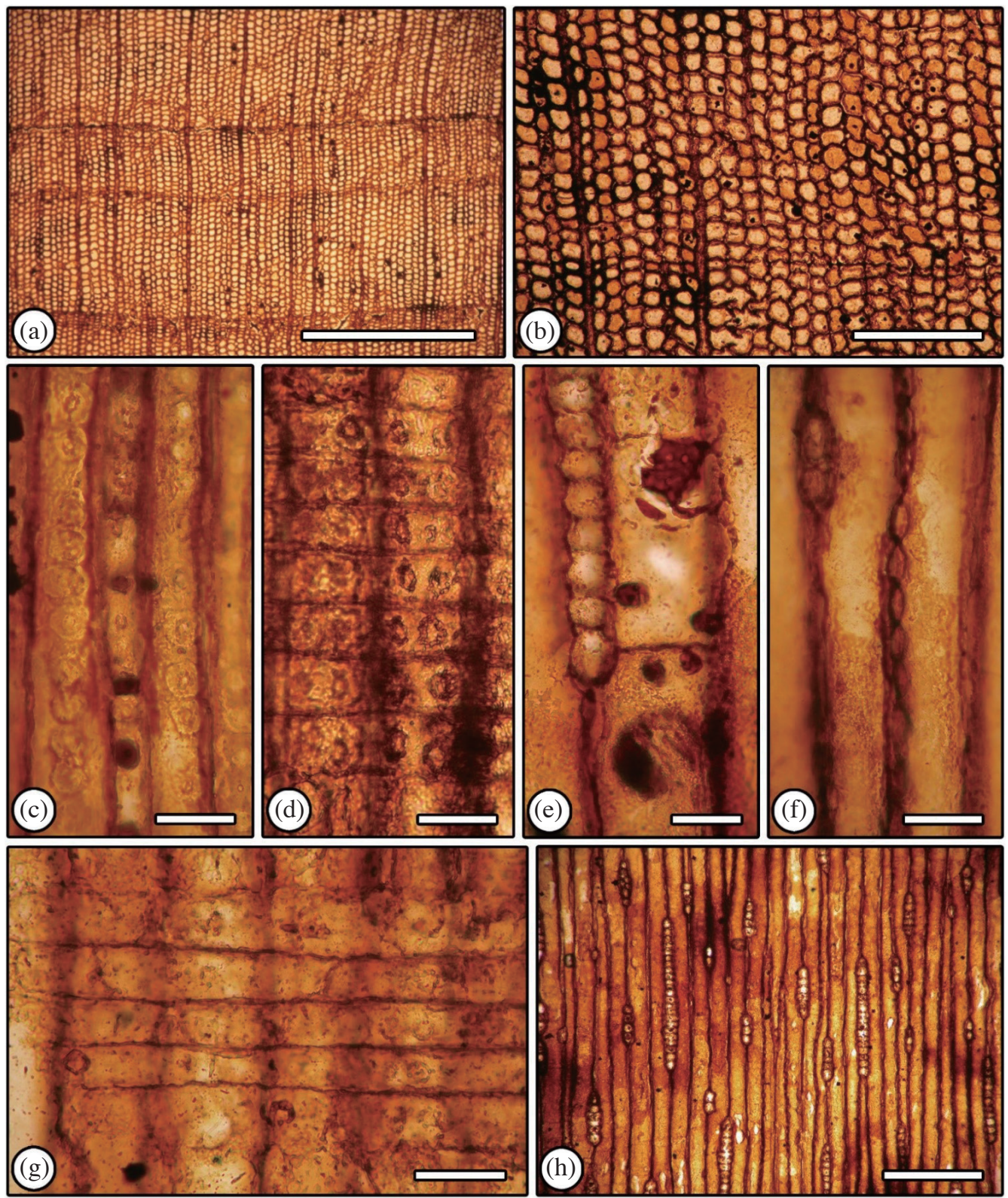

Fig. 2. Wood structure of Podocarpoxylon nageioides Y.-P. Lo and J.-M. Hu, sp. nov. (WL001). (a) Transverse section showing indistinct growth ring boundaries and abundant, diffuse axial parenchyma. Scale bar $=1 \mathrm{~mm}$. (b) Transverse section showing the shape of tracheids, square to polygonal. Scale bar $=250 \mu \mathrm{m}$. (c) Radial section showing the intertracheary radial pitting uniseriate. Scale bar $=40 \mu \mathrm{m}$. (d) Radial section showing cupressoid to taxodioid cross-field pits. Scale bar $=25 \mu \mathrm{m}$. (e) Tangential section showing end walls of axial parenchyma smooth. Scale bar $=25$ $\mu \mathrm{m}$. (f) Tangential section showing intertracheary radial pits and torus. Scale bar $=40 \mu \mathrm{m}$. (g) Radial section showing end and horizontal walls of ray parenchyma smooth and thin. Scale bar $=40 \mu \mathrm{m}$. (h) Tangential section showing ray parenchyma uniseriate and cells height. Scale bar $=250 \mu \mathrm{m}$. 
description of Philippe and Bamford (2008), Podocarpoxylon is a gymnosperm wood, with round, large, not contiguous radial pits; when multiseriate opposite. It lacks tertiary spiral thickenings. Ray cells without Abietineentüpfelung [Rounded pits, areolate or not, occurring on the transverse (tangential) wall of ray cells]; axial parenchyma regularly occurring. Cross-field with mostly 1 - 2 pits per field, podocarpoid to partly unbordered (Gothan 1905; Philippe and Bamford 2008). However, the cross-field pits podocarpoid is not the term included in IAWA Committee (2004). Philippe and Bamford (2008) noted that the feature "podocarpoid", which means the pits with narrow slit-like subvertical aperture, was used by Gothan to distinguish from the "cupressoid". Several reports of softwood anatomy have combined podocarpoid with cupressoid as variability because the difference of aperture inclination is not obvious (Phillips 1948; Barefoot and Hankins 1982; Philippe and Bamford 2008).

There are at least 91 species were identified to Podocarpoxylon and published by researchers since Gothan erected this genus in 1905, the fossil records can be found in all continents, from Mesozoic to Cenozoic (Pujana and Ruiz 2017). In Asia, the fossils of Podocarpoxylon were found in China and Japan (Shenzhen Fairy Lake Botanical Garden 2013). Table 1 provides the Podocarpoxylon species from the Cenozoic, for comparison with the features of the sample from Wanli. The key features among the species are the existence or abundance of axial parenchyma and the height of ray cells. And some species that found in near region such as P. donghuaiense Li, Jin, Quan, and Oskolski, from Ecoene, China, can be distinguish from the sample from
Wanli by the features of the distinct growth ring, absence of axial parenchyma and the number of cross-fied pits. P. multiparenchymatosum, from Ecoene, Patagonia, is the most similar species to $P$. nageioides, but with disparity of age and locality and the slight difference of the cross-field pits number, still can distinguish these samples (Table 1).

\section{DISCUSSION}

In this study, we decide to be more conservative for the identification of the Wanli fossil wood sample by not placing it under the modern genus name. The main reason is that the extant genera of Podocarpaceae have some taxonomic confusion themselves in wood anatomy, for example, Nage$i a$ has several features similar to some species of Podocarpus, such as abundant axial parenchyma and cross-field pits cupressoid in wood anatomical structure. The taxonomic position of Nageia is processed in various ways by different researchers, and had been treated as a section of Podocarpus in some reports before (Wang et al. 1999). However, in recent studies, morphological classification combined with molecular systematics supports Nageia as a segregated genus that belongs to Podocarpaceae and could be distinguished from Podocarpus (Kelch 1997; Biffin et al. 2012; Knopf et al. 2012). In addition, extant genera do not have a diagnosis and specificity in wood anatomy, and identifying the sample to extant genera only by the wood structure is somewhat subjective. On the other hand, fossil wood genera have diagnostic features, so that the placement is much more objective.

There are some records of Nageia fossils reported in

Table 1. Comparison of the features of Podocarpoxylon fossil wood from the Cenozoic with Podocarpoxylon nageioides Y.-P. Lo and J.-M. Hu, sp.nov.

\begin{tabular}{|c|c|c|c|c|c|c|c|c|}
\hline Species & Age & Locality & $\begin{array}{c}\text { Growth } \\
\text { ring }\end{array}$ & $\begin{array}{c}\text { Axial } \\
\text { parenchyma }\end{array}$ & $\begin{array}{c}\text { Radial pits } \\
\text { (-seriate) }\end{array}$ & $\begin{array}{c}\text { Ray height } \\
\text { (cells) }\end{array}$ & Cross-field & Reference \\
\hline $\begin{array}{c}\text { Podocarpoxylon } \\
\text { nageioides Y.-P. Lo } \\
\text { and J.-M. Hu, sp. nov. }\end{array}$ & Miocene & Taiwan & indistinct & $\begin{array}{c}\text { abundant to } \\
\text { sparse, diffuse }\end{array}$ & 1 & 1 - 29, average 6 & $\begin{array}{l}1-2 \text { pits, mostly } \\
2, \text { cupressoid and } \\
\text { taxodioid }\end{array}$ & This article \\
\hline P. aegyptiacum Kräusel & Oligocene & Egypt & distinct & abundant & $1-2$ & mostly 3 - 6 & $\begin{array}{l}\text { Pits inclined and } \\
\text { narrow elliptical, } \\
\text { almost vertical }\end{array}$ & Kräusel (1939) \\
\hline $\begin{array}{l}\text { P. aparenchymatosum } \\
\text { Gothan }\end{array}$ & Eocene & Antarctica & distinct & absent & $\begin{array}{c}\text { no describle } \\
\text { (Gothan 1908) } \\
1-3 \text { (Pujana } \\
\text { et al. 2014) }\end{array}$ & $1-17$, average 9 & $\begin{array}{l}1-5 \text { pits,mostly } \\
2 \text {, taxodioid (Pu- } \\
\text { jana et al. 2014) }\end{array}$ & $\begin{array}{c}\text { Gothan } \\
\text { (1908); Pujana } \\
\text { et al. (2014) }\end{array}$ \\
\hline $\begin{array}{l}\text { P. articulatum Süss and } \\
\text { Velitzelos }\end{array}$ & Lower Miocene & Greece & distinct & sparse & $1-2$ & $\begin{array}{c}1-100 \\
\text { mostly } 1-20\end{array}$ & $\begin{array}{l}1-3 \text { pits, } \\
\text { podocarpoid }\end{array}$ & $\begin{array}{l}\text { Süss and } \\
\text { Velitzelos } \\
(2000)\end{array}$ \\
\hline$P$. australe Kräusel * & Oligocene & Australia & $\begin{array}{l}\text { indistinct } \\
\text { or absent }\end{array}$ & sparse, diffuse & 1 & $1-12$, average 4 & $\begin{array}{l}1-3 \text { pits, usu- } \\
\text { ally } 1 \text {, pits oval } \\
\text { and pore of pits } \\
\text { narrow, oblique, } \\
\text { reaching the bor- } \\
\text { der at either end }\end{array}$ & Patton (1958) \\
\hline
\end{tabular}

Note: * The reference list of species was lack of original publication. 
Table 1. (Continued)

\begin{tabular}{|c|c|c|c|c|c|c|c|c|}
\hline Species & Age & Locality & $\begin{array}{l}\text { Growth } \\
\text { ring }\end{array}$ & $\begin{array}{c}\text { Axial } \\
\text { parenchyma }\end{array}$ & $\begin{array}{l}\text { Radial pits } \\
\text { (-seriate) }\end{array}$ & $\begin{array}{l}\text { Ray height } \\
\text { (cells) }\end{array}$ & Cross-field & Reference \\
\hline $\begin{array}{l}\text { P. bruxellense } \\
\text { Stockmans }\end{array}$ & Eocene & Belgium & distinct & abundant & 1 & $2-17$, average 7 & $\begin{array}{l}1, \text { large, oblique } \\
\text { to vertical }\end{array}$ & $\begin{array}{l}\text { Stockmans } \\
(1936)\end{array}$ \\
\hline $\begin{array}{l}\text { P. deccanensis Trivedi } \\
\text { and Srivastava }\end{array}$ & Tertiary & India & faint & $\begin{array}{l}\text { diffuse, resin- } \\
\text { iferous }\end{array}$ & 1 & $\begin{array}{c}2-45 \text {, average } \\
2-17\end{array}$ & $\begin{array}{l}\text { 1, large, } \\
\text { taxodioid }\end{array}$ & $\begin{array}{l}\text { Trivedi and } \\
\text { Srivastava } \\
\text { (1989) }\end{array}$ \\
\hline $\begin{array}{l}\text { P.donghuaiense Li, } \\
\text { Jin, Quan and Oskolski }\end{array}$ & Ecoene & China & distinct & absent & $1-2$ & $1-16$, average 5 & $\begin{array}{l}1-4, \text { mean } 2, \\
\text { cupressoid and } \\
\text { taxodioid }\end{array}$ & Li et al. (2016) \\
\hline $\begin{array}{c}P . \text { fildesense Zhang and } \\
\text { Wang }\end{array}$ & $\begin{array}{l}\text { Paleocene } \\
\text { (Zhang and } \\
\text { Wang 1994) }\end{array}$ & Antarctica & distinct & diffuse & 1 & $\begin{array}{c}1-16, \text { mostly } \\
2-8 \text { (Zhang and } \\
\text { Wang 1994) }\end{array}$ & $\begin{array}{c}1-2, \text { sometimes } \\
4 \text {, podocarpoid }\end{array}$ & $\begin{array}{c}\text { Zhang and } \\
\text { Wang (1994); } \\
\text { Poole et al. } \\
(2001)\end{array}$ \\
\hline $\begin{array}{l}P . \text { graciliradiatum Süss } \\
\text { and Velitzelos }\end{array}$ & Lower Miocene & Greece & distinct & abundant & $1-2$ & $\begin{array}{c}1-70, \text { mostly } \\
1-30\end{array}$ & $\begin{array}{l}1-3 \text { pits, } \\
\text { podocarpoid }\end{array}$ & $\begin{array}{l}\text { Süss and } \\
\text { Velitzelos } \\
(2000)\end{array}$ \\
\hline P. kubarti Rössler R & Pliocene & Australia & indistinct & sparse & 1 & $1-23$ & $\begin{array}{l}1 \text { - } 3 \text {, rarely } \\
4, \text { with wide } \\
\text { apecture }\end{array}$ & Rössler (1937) \\
\hline $\begin{array}{c}\text { P. kutchensis } \\
\text { Lakhanpal, Guleria and } \\
\text { Awasthi }\end{array}$ & $\begin{array}{l}\text { Pliocene-Pleis- } \\
\text { tocene }\end{array}$ & India & distinct & sparse, diffuse & $1-2$ & $\begin{array}{l}2-50, \text { average } \\
2-25\end{array}$ & $\begin{array}{l}\text { no record due to } \\
\text { poor preservation }\end{array}$ & $\begin{array}{c}\text { Guleria and } \\
\text { Shukla (2011) }\end{array}$ \\
\hline $\begin{array}{c}\text { P. latrobensis } \\
\text { Greenwood }\end{array}$ & Miocene & Australia & indistinct & rare to absent & $1-2$ & $\begin{array}{c}2-18, \text { average } \\
5-12\end{array}$ & $\begin{array}{c}1, \text { rarely } 2, \\
\text { podocarpoid }\end{array}$ & $\begin{array}{l}\text { Greenwood } \\
(2005)\end{array}$ \\
\hline $\begin{array}{l}\text { P. mahabalei (Agashe) } \\
\text { Trivedi and Srivastava }\end{array}$ & Tertiary & India & distinct & sparse & 1 & $\begin{array}{c}1-30 \\
\text { average } 11\end{array}$ & 1 , bordered & $\begin{array}{l}\text { Trivedi and } \\
\text { Srivastava } \\
(1989)\end{array}$ \\
\hline $\begin{array}{c}\text { P. mazzonii } \\
\text { (Petriella) Müller-Stoll } \\
\text { and Schultze-Motel * }\end{array}$ & $\begin{array}{c}\text { Upper Paleo- } \\
\text { cene-Eocene } \\
\text { (Raigemborn et } \\
\text { al. 2009) } \\
\text { Paleocene } \\
\text { (Brea et al. } \\
\text { 2011) }\end{array}$ & Argentina & indistinct & $\begin{array}{l}\text { diffuse (Brea } \\
\text { et al. 2011) }\end{array}$ & $1-2$ & $\begin{array}{c}5-17 \text {, average } \\
9 \text { (Raigemborn } \\
\text { et al. 2009) / } \\
4-24 \text {, average } \\
13 \text { (Brea et al. } \\
\text { 2011) }\end{array}$ & $\begin{array}{l}\text { 1, large apertures } \\
\text { and thin weakly- } \\
\text { defined borders } \\
\text { (Raigemborn et } \\
\text { al. 2009) / } 1 \text { - } 2 \text {, } \\
\text { cupressoid (Brea } \\
\text { et al. 2011) }\end{array}$ & $\begin{array}{c}\text { Raigemborn } \\
\text { et al. (2009); } \\
\text { Brea et al. } \\
(2011)\end{array}$ \\
\hline P. minor Patton & Oligocene & Australia & indistinct & sparse diffuse & 1 & $1-7$, average 2 & $\begin{array}{c}1-3 \text { pits, usually } \\
1, \text { pits oval and } \\
\text { apertures narrow }\end{array}$ & Patton (1958) \\
\hline $\begin{array}{l}\text { P. multiparenchymato- } \\
\text { sum Pujana and Ruiz }\end{array}$ & Eocene & Patagonia & indistinct & abundant & 1 & $\begin{array}{c}2-24 \text {, average } \\
7.9\end{array}$ & $\begin{array}{l}1, \text { rarely } 2, \\
\text { taxodioid or } \\
\text { podocarpoid }\end{array}$ & $\begin{array}{l}\text { Pujana and } \\
\text { Ruiz (2017) }\end{array}$ \\
\hline $\begin{array}{l}\text { P. sahnii (Ramanujam) } \\
\text { Trivedi and Srivastava }\end{array}$ & Tertiary & India & distinct & absent & 1 & 1 - 20, average 8 & $\begin{array}{l}\text { 1, fusiform, } \\
\text { single }\end{array}$ & $\begin{array}{l}\text { Trivedi and } \\
\text { Srivastava } \\
\text { (1989) }\end{array}$ \\
\hline P. schwendae Kubart & Cenozoic & Austria & distinct & $\begin{array}{l}\text { present but not } \\
\text { describe extent }\end{array}$ & $1-2$ & $1-13$ & $\begin{array}{l}1-2, \text { podocar- } \\
\text { poid }\end{array}$ & Kubart (1911) \\
\hline $\begin{array}{c}\text { P. speciosum } \\
\text { (Ramanujam) Trivedi } \\
\text { and Srivastava }\end{array}$ & Tertiary & India & distinct & abundant & $1-2$ & $1-18$, average 6 & 2 - 4, bordered. & $\begin{array}{l}\text { Trivedi and } \\
\text { Srivastava } \\
(1989)\end{array}$ \\
\hline $\begin{array}{l}\text { P. tiruvakkaraianum } \\
\text { (Ramanujam) Trivedi } \\
\text { and Srivastava }\end{array}$ & Tertiary & India & faint & sparse & $1-2$ & $\begin{array}{c}3-50 \text {, average } \\
18\end{array}$ & 1, large, simple. & $\begin{array}{l}\text { Trivedi and } \\
\text { Srivastava } \\
(1989)\end{array}$ \\
\hline P. yallournensis Patton & Oligocene & Australia & indistinct & $\begin{array}{l}\text { abundant, } \\
\text { diffuse }\end{array}$ & $1-2$ & $1-6$, average 2 & $\begin{array}{l}1-5 \text { pits, usually } \\
1-3 \text {, pits shape } \\
\text { variable, aperture } \\
\text { broad or narrow. }\end{array}$ & Patton (1958) \\
\hline
\end{tabular}


recent decades. Yang et al. (1990) reported a fossil wood of Nageia nagi (= Podocarpus nagi) based on the anatomical features from the Cretaceous, in Dabie Mountains, China. Jin et al. (2010) reported that a leaf fossil of Nageia from the Cenozoic strata in south China, identified as genus Negeia with the features of midvein absent (as in all Nageia) and distinguished from other Podocarpaceae species. Considering the characteristic of wood without decisive features and age, the sample from Wanli should not be identified as the extent species of Negeia directly and better to be treated as fossil species conservatively, despite the distribution and several features are similar to extent genus Nageia.

The discovery of Podocarpaceae indicates that the Miocene environment should have been tropical or subtropical. In addition, the growth ring boundary indistinct with narrow latewood is also a characteristic suggesting the weather should have been warm. The evidence is congruent with the result of other macrofossils reports and the palynology of the Miocene in Taiwan. The Cenozoic has two pollen records of Podocarpaceae genera in Taiwan, Dacrydimites and Podocarpidites (Huang 1979, 2006; Shaw 2000) and according to $\mathrm{Li}$ (2000), the evidence of leaves and pollen fossils from the Miocene provides the same speculation (Li 2000; Uemura and Li 2006). The specimens in this article show the first macrofossil record and a new species of Podocarpaceae in Taiwan, provide a new reference for the paleo-flora. We hope that there will be more plant fossils unearthed in Taiwan, and the result should provide valuable information on the construction of paleoenvironment and paleoclimate, and also provide the evidence of ancient biodiversity and historical biogeography.

\section{CONCLUSION}

A new fossil species of Podocarpaceae, Podocarpoxylon nageioides Y.-P. Lo and J.-M. Hu, sp. nov. is described from the Miocene of Northern Taiwan, and the anatomy of the fossil wood is similar to modern species of Nageia. Considering its geological age, we excluded our sample from the extant genus Nageia and place it in the fossil genus Podocarpoxylon based on the wood anatomical features. We described it as a new species distinguished from other Cenozoic Podocarpoxylon species based on the combination of following features: indistinct growth ring; radial pits uniseriate; axial parenchyma abundant to sparse, diffuse, and not tangentially zonate; 1 - 2 cupressoid or taxodioid pits in cross-field; ray with $1-29$ cells high.

According to the habitat of extant Podocarpaceae species and the feature of indistinct and narrow latewood of growth ring of our sample, it suggests a warm environment in Miocene, northern Taiwan. We speculated the climate should be tropical or subtropical, also conform to the results of other plant fossils from the Miocene in Taiwan.
Acknowledgements We thank for the help of rock thin section processing from Geology Department, National Museum of Natural Science, Taiwan, and thank for the helpful suggestion of geology and fossil collection from Dr. WenShan Chen and Dr. Jih-Pai Lin, Department of Geosciences, National Taiwan University. We would also like to thank for the meaningful advice from reviewers.

\section{REFERENCES}

Bamford, M. K. and M. Philippe, 2001: Jurassic-Early Cretaceous Gondwanan homoxylous woods: A nomenclatural revision of the genera with taxonomic notes. Rev. Palaeobot. Palynology, 113, 287-297, doi: 10.1016/ S0034-6667(00)00065-8. [Link]

Barefoot, A. C. and F. W. Hankins, 1982: Identification of Modern and Tertiary Woods, Oxford University Press, $189 \mathrm{pp}$.

Biffin, E., T. J. Brodribb, R. S. Hill, P. Thomas, and A. J. Lowe, 2012: Leaf evolution in Southern Hemisphere conifers tracks the angiosperm ecological radiation. Proc. R. Soc. B-Biol. Sci., 279, 341-348, doi: 10.1098/ rspb.2011.0559. [Link]

Brea, M., S. D. Matheos, M. S. Raigemborn, A. Iglesias, A. F. Zucol, and M. B. Prámparo, 2011: Paleoecology and paleoenvironments of Podocarp trees in the Ameghino Petrified forest (Golfo San Jorge Basin, Patagonia, Argentina): Constraints for Early Paleogene paleoclimate. Geologica Acta, 9, 13-28, doi: 10.1344/105.000001647. [Link]

Canright, J. E., 1972: Evidence of the existence of Metasequoia in the Miocene of Taiwan. Taiwania, 17, 222228, doi: 10.6165/tai.1972.17.222. [Link]

Chaney, R. W. and C.-C. Chuang, 1968: An oak-laurel forest in the Miocene of Taiwan (Part 1). Proc. Geol.Soc. China, 11, 3-18.

Chen, W. S. and N. T. Yu, 2016: The Foothills Region in Western Taiwan. In: Chen, W. S. (Ed.), Introduction of Geology in Taiwan, Geol. Soc. Taiwan Press, 53-90. (in Chinese)

Cheng, J. Q., J. J. Yang, and P. Liu, 1992: Timbers of China, China Forestry Publishing House Press, Beijing, 1034 pp. (in Chinese)

Chou, J.-T., 1962: Stratigraphic and sedimentary study of the Mushan Formation in northern Taiwan. Petrol. Geol. Taiwan, 1, 87-119.

Dupéron-Laudoueneix, M. and D. Pons, 1985: Nouvelle étude de Mesembrioxylon libanoticum Edwards (Conifère du Mésozoïque supérieur); intérêts paléogéographigue, biostratigraphique et paléoclimatique. Giornale Botanico Italiano, 119, 151-166, doi: 10.1080/11263508509428013. [Link]

Eckenwalder, J. E., 2009: Conifers of the World: The 
Complete Reference, Timber Press, Portland, 744 pp.

Editorial Committee of the Red List of Taiwan Plants, 2017:

The Red List of Vascular Plants of Taiwan, Endemic Species Research Institute, Forestry Bureau, Council of Agriculture, Executive Yuan and Taiwan Society of Plant Systematics Press, 187 pp.

Franco, M. J. and M. Brea, 2015: First extra-Patagonian record of Podocarpaceae fossil wood in the Upper Cenozoic (Ituzaingó Formation) of Argentina. N.Z. J. Bot., 53, 103-116, doi: 10.1080/0028825X.2015.1029055. [Link]

Gothan, W., 1905: Zur Anatomie Lebender und Fossiler Gymnospermen-Hölzer, In Vertrieb bei der Königlichen Geologischen Landesanstalt und Bergakademie, $108 \mathrm{pp}$.

Gothan, W., 1908: Die Fossilen Hölzer von der Seymourund Snow Hill-Insel, Wissenschaftliche Ergebnisse der Schwedischen Südpolar-Expedition 1901 - 1903,33 pp.

Greenwood, D. R., 2005: Miocene wood from the LaTrobe Valley coal measures, Victoria, Australia. Alcheringa, 29, 351-363, doi: 10.1080/03115510508619311. [Link]

Greguss, P., 1955: Identification of Living Gymnosperms on the Basis of Xylotomy, Akadémiai Kiadó Press, Budapest, $263 \mathrm{pp}$.

Guleria, J. S. and A. Shukla, 2011: Gymnospermous woods from the Late Cenozoic sediments of Rajasthan, western India. Palaeobotanist, 60, 355-362.

Heinz, I., 2004: Systematische Erfassung und Doku-mentation der mikroanatomischen Merkmale der Nadelhölzer aus der Klasse der Pinatae. Ph.D. Thesis, Technical University, München, 209 pp.

Ho, C.-S., 1966: The Shihti Formation in Northern Taiwan. Bull. Geol. Surv. Taiwan, 17, 1-25.

Huang, T.-C., 1979: Miocene Palynomorphs of Taiwan (IV)-Gymnospermous grains. Taiwania, 24, 81-105, doi: 10.6165/tai.1979.24.81. [Link]

Huang, T.-C., 2006: Plant Taxonomy: Families of Taiwan Vascular Plants, SMC Publishing Press, Taipei, Taiwan, 661 pp. (in Chinese)

IAWA Committee, 2004: IAWA list of microscopic features for softwood identification. IAWA J., 25, 1-70, doi: 10.1163/22941932-90000349. [Link]

Jiang, X., Y. Cheng, and Y. Yin, 2010: Atlas of Gymnosperms Woods of China, Science Press, Beijing, 490 pp. (in Chinese)

Jin, J., J. Qiu, Y. Zhu, and T. M. Kodrul, 2010: First fossil record of the genus Nageia (Podocarpaceae) in south China and its phytogeographic implications. Plant Syst. Evol., 285, 159-163, doi: 10.1007/s00606-0100267-4. [Link]

Kelch, D. G., 1997: The Phylogeny of the Podocarpaceae based on morphological evidence. Syst. Bot., 22, 113131, doi: 10.2307/2419680. [Link]
Knopf, P., C. Schulz, D. P. Little, T. Stützel, and D. W. Stevenson, 2012: Relationships within Podocarpaceae based on DNA sequence, anatomical, morphological, and biogeographical data. Cladistics, 28, 271-299, doi: 10.1111/j.1096-0031.2011.00381.x. [Link]

Kräusel, R., 1939: Ergebnisse der Forschungsreisen Prof. E. Stromers in den Wüsten Ägyptens: IV. Die Fossilen Floren Ägyptens: 3. Die Fossilen Pflanzen Ägyptens, Abhandlungen der Bayerischen Akademie der Wissenschaften, Mathematisch-naturwissenschaftliche Abteilung 47, Alexander Doweld, 140 pp.

Kubart, B., 1911: Podocarpoxylon schwendae, ein fossiles Holz vom Attersee (Oberösterreich). Österreichische Botanische Zeitschrift, 61, 161-177, doi: 10.1007/ bf01631435. [Link]

Li, C.-Y., 2000: A study on Miocene floras in Taiwan. Ph.D. Thesis, National Chung Hsing University, Taichung, Taiwan, 115 pp. (in Chinese)

Li, C.-Y., J.-Y. Hsiao, and C.-H. Yang, 1999: Fossil woods of Taxodiaceae from the Kungkuan Tuff (Early Miocene) of northern Taiwan. Collection and Research, 12, 41-48, doi: 10.6693/CAR.1999.12.3. [Link]

Li, C.-Y., C.-M. Wang, J.-Y. Hsiao, and C.-H. Yang, 2003: Two fossil dicotyledonous woods from the Kungkuan Tuff (Early Miocene), northern Taiwan. Collection and Research, 16, 71-78, doi: 10.6693/CAR.2003.16.8. [Link]

Li, H. L., H. Keng, Y. P. Yang and S. Y. Lu 1994: Podocarpaceae. In: Huang, T.-C., W.-C. Shieh, H. Keng, J.-L. Tsai, and C.-F. Hsieh (Eds.), Flora of Taiwan $2^{\text {nd }}$ volume one, Ed. Comm. of Flora of Taiwan Sec. Ed. Press, 557-566.

Li, L., J.-H. Jin, C. Quan, and A. A. Oskolski, 2016: First record of Podocarpoid fossil wood in South China. Sci. Rep., 6, 32294, doi: 10.1038/srep32294. [Link]

Patton, R. T., 1958: Fossil wood from Victorian brown coal. Proc. Roy. Soc. Victoria, 70, 129-143.

Peters, S. E. and M. McClennen, 2016: The Paleobiology Database application programming interface. Paleobiology, 42, 1-7, doi: 10.1017/pab.2015.39. [Link]

Philippe, M. and M. K. Bamford, 2008: A key to morphogenera used for Mesozoic conifer-like woods. Rev. Palaeobot. Palynology, 148, 184-207, doi: 10.1016/j. revpalbo.2007.09.004. [Link]

Philippe, M. and V. Wilde, 2020: Kräusel's eight genera for fossil softwoods: Types, nomenclature, and taxonomy. IAWA J., 42, 81-91, doi: 10.1163/22941932-bja 10039. [Link]

Philippe, M., G. Zijlstra, and M. Barbacka, 1999: Greguss's morphogenera of homoxylous fossil woods: A taxonomic and nomenclatural review. Taxon, 48, 667-676, doi: 10.2307/1223638. [Link]

Phillips, E. W. J., 1948: Identification of Softwoods by Their Microscopic Structure, H.M. Stationery Office, 
London, $55 \mathrm{pp}$.

Poole, I., R. J. Hunt, and D. J. Cantrill, 2001: A fossil wood flora from King George Island: Ecological implications for an antarctic Eocene vegetation. Ann. Bot., 88, 33-54, doi: 10.1006/anbo.2001.1425. [Link]

Pujana, R. R. and D. P. Ruiz, 2017: Podocarpoxylon Gothan reviewed in the light of a new species from the Eocene of Patagonia. IAWA J., 38, 220-244, doi: 10.1163/22941932-20170169. [Link]

Pujana, R. R., S. N. Santillana, and S. A. Marenssi, 2014: Conifer fossil woods from the La Meseta Formation (Eocene of Western Antarctica): Evidence of Podocarpaceae-dominated forests. Rev. Palaeobot. Palynology, 200, 122-137, doi: 10.1016/j.revpalbo.2013.09.001. [Link]

Raigemborn, M. S., M. Brea, A.F.Zucol, and S. D. Matheos, 2009: Paleoecology and paleoenvironments of Podocarp trees in the Ameghino Petrified forest (Golfo San Jorge Basin, Patagonia, Argentina): Constraints for Early Paleogene paleoclimate. Geologica Acta, 7, 125145, doi: 10.1344/105.000000269. [Link]

Rössler, W., 1937: Pliozäne Koniferenhölzer der Umgebung von Gleichenberg in Steiermark. Mitt. Naturwiss. Ver. Steiermark, 74, 64-97.

Shaw, C.-L., 2000: Eocene Gymnospermous palynomorphs of Taiwan. Taiwania, 45, 13-29, doi: 10.6165/ tai.2000.45(1).13. [Link]

Shenzhen Fairy Lake Botanical Garden, 2013: An Introduction to the World's Petrified Wood, Geological Publishing House Press, Beijing, 680 pp. (in Chinese)

Stockmans, F., 1936: Végétaux éocènes des environs de Bruxelles. Memoirs of the Royal Belgian Museum of Natural Sciences, 76, 3-56.

Süss, H. and E. Velitzelos, 2000: Zwei neue fossile Höl- zer der Formgattung Podocarpoxylon Gothan aus tertiären Schichten der Insel Lesbos, Griechenland. Feddes Repertorium, 111, 135-149, doi: 10.1002/ fedr.20001110304. [Link]

Trivedi, B. S. and R. Srivastava, 1989: Gymnospermous woods from Early Tertiary of Chhindwara District of Madhya Pradesh. Phytomorphology, 39, 61-68.

Uemura, K. and C.-Y. Li, 2006: Miocene floras of Taiwan: An overview in comparison with those of southwestern end of Japan. Mem. Natn. Sci. Mus., Tokyo, 44, 185-193.

Wang, T., Y.-J. Su, C. Huang, and J.-M. Zhu, 1999: RAPD analyses of Nageiaoids. Acta Bot. Yunnanica, 21, 144-148.

Wheeler, E. A., 2011: Inside Wood - A web resource for hardwood anatomy. IAWA J., 32, 199-211, doi: 10.1163/22941932-90000051. [Link]

Yang, J. J., G. F. Qi, and R. H. Xu, 1990: Studies on fossil woods excavated from the Dabie Mountains. Scientia Silvae Sinicae, 26, 379-383. (in Chinese)

Yang, Y., Z. Wang, and X. Xu, 2017: Taxonomy and Distribution of Global Gymnosperms, Shanghai Scientific and Technical Publishers Press, Shanghai, 1223 pp. (in Chinese)

Yue, L.-F. and L. S.-Y. Teng, 2000: Sedimentary facies and depositional cycles of the mushan formation. Bulletin of the Central Geological Survey, 13, 157-194. (in Chinese)

Zhang, S. Z. and Q. Z. Wang, 1994: Paleocene petrified wood on the west side of Collins Glacier in the King George Island, Antarctica. In: Shen, Y. B. (Ed.), Stratigraphy and Palaeontology of Fildes Peninsula, King George Island, Antarctica, Science Press, Beijing, China, 223-238. (in Chinese) 